\title{
Atrial natriuretic factor
}

\section{Possible implications in liver disease}

\author{
A.L. Gerbes, R.M. Arendt and G. Paumgartner \\ Departments of Medicine II and I, Klinikum Grosshadern, University of Munich, Munich (F.R.G.)
}

(Accepted 26 February, 1987)

The pathophysiology of renal sodium retention and ascites formation in patients with cirrhosis of the liver has become progressively more complicated [1]. Conflicting theories of 'underfilling' and 'overflow' [2] have been developed to explain the afferent mechanisms of impaired volume homeostasis in cirrhosis. Investigations of efferent mechanisms proved to be equally perplexing. Stimulation of the ReninAngiotensin-Aldosterone system may be of importance for sodium reabsorption [3], but there is increasing evidence that this is but one of several factors $[4,5]$. Thus, the impact of other hormonal and neural systems on sodium retention was investigated, such as the sympathetic nervous system $[6,7]$, vasopressin [8], prostaglandins $[9,10]$ and kallikrein-kinin [11]. For about two decades, the existence of a circulating natriuretic substance with digoxin-like immunoreactivity, with vasoactive and $\mathrm{Na}^{+} / \mathrm{K}^{+}$-ATPase inhibiting properties has been postulated [12-15]. A deficiency of this natriuretic substance was hypothesized to be relevant for fluid and electrolyte disturbances in chronic liver disease [16]. However, the inability to satisfactorily characterize and determine this putative natriuretic hormone rendered difficult the elucidation of its role [17].

\section{Atrial Natriuretic Factor (ANF) - a novel volume- regulating hormone}

As early as 1847 , the heart was attributed an important role in volume regulation by inducing diuresis following the volume-loading of water immersion [18]: '.. if the blood be thus driven (by water immersion) from the external and internal parts, what becomes of the blood? The heart and great vessels, it would seem, must be burdened. Such is to a degree the case; and it is perhaps the stimulus of this fullness and distension or its action on the elasticity of those great vessels and the heart that constitutes the reaction (which leads forth the urine in abundant effusion).' More than 100 years later, Gauer and Henry demonstrated that it was the atria which enhanced water and sodium excretion upon an increase in central blood volume $[19,20]$. Independently, and unaware of this physiologic research, workers performing electron-microscopic studies found multiple dense granules in the cytoplasm of atrial muscle cells $[21,22]$. Uniting the physiological importance of the atria with this morphological feature of secretory atrial myocytes, DeBold in 1981 found a natriuretic response to intravenous injection of atrial extracts

Correspondence: A.L. Gerbes, Department of Medicine II, Klinikum Grosshadern, University of Munich, Munich, F.R.G. 


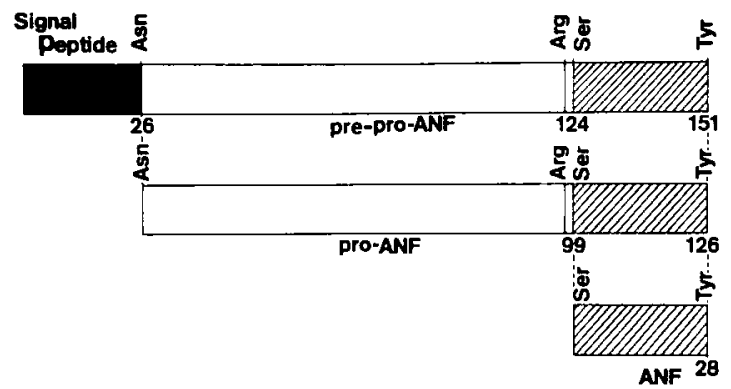

Fig. 1. Schematic representation of human ANF. Amino acid sequence is read from the amino (N)-terminus (left) to the carboxy (C)-terminus (right)

[23]. It took only 3 more years to identify the Atrial Natriuretic Factor (ANF) as a peptide (for a schematic representation of human ANF, see Fig. 1), and to date many of its important properties have been characterized.

For a better understanding of the possible implications of this novel volume-regulating hormone in liver disease, some significant features of ANF are summarized below (see reviews, Refs. 24-34, for comprehensive information).

The biosynthesis of human ANF resembles that of most secreted peptides: transcribed messenger RNA is translated to a 151-amino-acid pre-prohormone ANF-151 with a hydrophobic signal peptide at the Nterminus (Fig. 1), which is supposed to expedite transport across the endoplasmic reticulum. Subsequent to cleavage of the signal peptide, ANF-126. the prohormone is stored in secretory vesicles. ANF126 is further processed enzymatically and secreted into the blood, where the biologically active C-terminal ANF-28 has been defined as the circulating hormone $[27,35,36]$. Increased dietary sodium intake has been shown to stimulate ANF release [37]. The initial observation that water immersion, increasing central venous pressure by shifting extracellular volume to the intrathoracic venous bed, rapidly increases ANF plasma levels in healthy human subjects [38] has been confirmed by several investigators $[39,40,40 a]$. Elevation of atrial pressure has been demonstrated to prompt ANF release [41]. ANF plasma levels can be determined by RIA; however. plasma levels measured in different research laboriltories in comparable groups of subjects may vary considerably (cf. Table 1). This may in part be due to different extraction procedures or tracer degradation. The 'International Collaborative Study of the Proposed International Standard for Atrial Natriuretic Factor on behalf of the American Heart Asso-

TABLE 1

\section{ANF PLASMA LEVELS IN PATIENTS WITH CIRRHOSIS (Ci)}

$+/$ A means (sub)group with/without ascites. Co: values in normal controls. $n$ : number of subjects. Values are means $\pm \mathrm{SE}, \mathrm{fmol} / \mathrm{ml}$. $3 \mathrm{pg}$ correspond to $1 \mathrm{fmol}$. Data in the table are basically taken from the referenced literature; data of several authors are supplimented by more recent information (personal communication).

\begin{tabular}{|c|c|c|c|c|c|c|c|c|}
\hline Author [Ref.] & Co & $n$ & $\mathrm{Ci}$ & $n$ & $\mathrm{Ci}+\mathrm{A}$ & $n$ & $\mathrm{Ci}-\mathrm{A}$ & $n$ \\
\hline Barakat [64] & $9 \pm 2$ & 5 & $161 \pm 63$ & 5 & & & & \\
\hline Bonkovsky [65] & $64 \pm 4$ & 11 & & & $46 \pm 3$ & 17 & $57 \pm 3$ & 12 \\
\hline Burghardt [66] & $9 \pm 1$ & 17 & $9 \pm 1$ & 58 & $8 \pm 1$ & 18 & $9 \pm 1$ & 16 \\
\hline Campbell [67] & & & & & $27 \pm 6$ & 4 & & \\
\hline Epstein [68] & $8 \pm 2$ & 13 & & & $10 \pm 3$ & 8 & & \\
\hline Fernandez-Cruz [69] & $28 \pm 2$ & 5 & & & $61 \pm 9$ & 8 & & \\
\hline Gerbes $[70]$ & $6 \pm 1$ & 22 & $9 \pm 1$ & 41 & $8 \pm 1$ & 10 & $8 \pm 1$ & 11 \\
\hline Ginés [71] & $4 \pm 1$ & 13 & $14 \pm 1$ & 35 & & & & \\
\hline Jüppner [72] & $33 \pm 3$ & 21 & $82 \pm 10$ & 33 & & & & \\
\hline Morgan [73] & $9 \pm 2$ & 14 & & & $120 \pm 23$ & 7 & & \\
\hline Nishiuchi [74] & $6 \pm 1$ & 54 & $46 \pm 14$ & 17 & & & & \\
\hline Nozuki [75] & $23 \pm 2$ & 28 & & & $17 \pm 4$ & 5 & & \\
\hline Renner [76] & $15 \pm 1$ & 106 & & & $31 \pm 4$ & 20 & $14 \pm 3$ & 10 \\
\hline Shenker [77] & $16 \pm 2$ & 10 & & & 20 & 4 & & \\
\hline
\end{tabular}


ciation/International Society of Hypertension/World Health Organisation' [42] will attempt to clarify the existing discrepancies. Furthermore, as antibodies recognize, to varying degrees, precursors or circulating fragments of ANF-28, characterization of the immunoreactivity determined is advisable, e.g., by HPLC techniques [43].

ANF binding sites have been found in renal glomerula as well as vasa recta, in cells of the adrenal zona glomerulosa, in vascular smooth muscle and endothelial cells and in various parts of the central nervous system. Cyclic guanosine monophosphate has been claimed to be the intracellular second messenger of ANF action [44]. Various physiologic actions of ANF in the organism are summarized in Fig. 2. Enhanced renal sodium and volume excretion are supposed to be in part due to an increase of the glomerular filtration rate as a result of alterations of renal hemodynamics induced by pre-glomerular vaso- dilation and post-glomerular vasoconstriction [45]. In part, actions at other renal sites may increase perfusion of the medullary papillary interstitial space. Indeed, ANF relaxes smooth muscles of different vascular sites with differing potency. Thus, infusion of ANF at doses not affecting systemic blood pressure can influence both renal and liver blood flow [46]. The observation that antisera to ANF reduce urinary sodium excretion and increase plasma renin activity [47] suggests a physiological role for this novel hormone in volume regulation.

Thus, it is by no means surprising that interactions with other hormonal systems involved in volume regulation have been reported: ANF counteracts the Renin-Angiotensin-Aldosterone axis [48] by reducing renin as well as aldosterone secretion and by relaxing angiotensin-constricted vessels [49-51]. It was speculated that ANF, elevated in primary aldosteronism [52], in turn might be stimulated by angiotensin

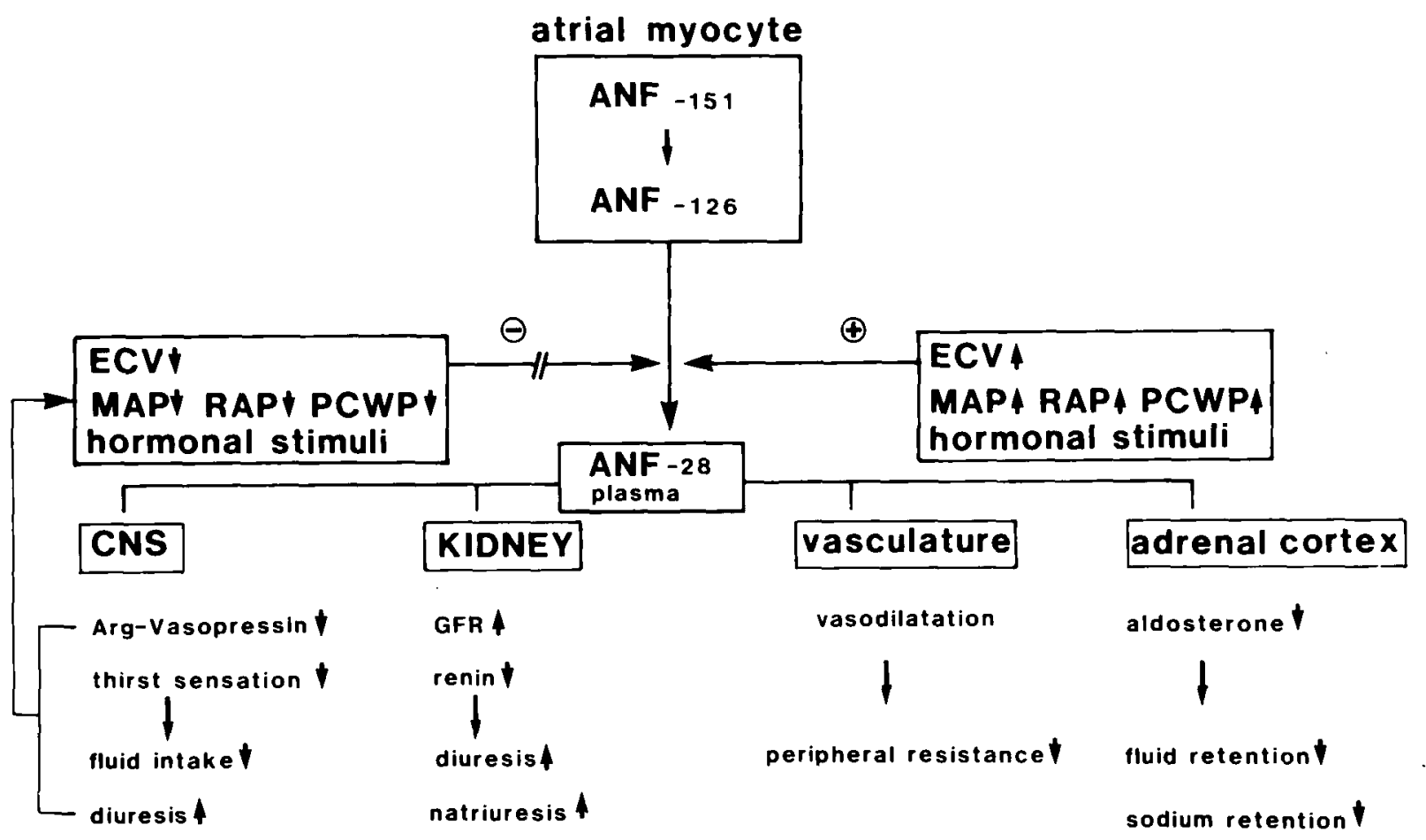

Fig. 2. Effects of ANF in the body. CNS = central nervous system, ECV = extracellular volume, GFR = glomerular filtration rate, $\mathrm{MAP}=$ mean arterial pressure, $\mathrm{PCWP}=$ pulmonary capillary wedge pressure, $\mathrm{RAP}=$ right atrial pressure. 
II, thus explaining the natriuresis observed after angiotensin infusion [53]. ANF is stimulated by mineralocorticoid administration [54,55], thus being a potential mediator of the 'escape phenomenon'; though it certainly is not identical with the $\mathrm{Na}^{+} / \mathrm{K}^{+}$-ATPaseinhibiting natriuretic hormone, ANF seems to be an excellent candidate for the long-elusive 'third factor' [56]. A number of observations suggest interactions of ANF with the sympathicoadrenergic system: Infusion of norepinephrine provokes ANF release from isolated rat hearts [57], this stimulation being inhibited by alpha-adrenoceptor blockade with phentolamine [57]; ANF may prevent norepinephrine-induced acute renal failure [58] and may reduce norepinephrine-induced blood pressure elevations [59]; and a relationship to vasopressin is suggested by the observation of an increased ANF secretion following vasopressin infusion $[60,61]$, whereas ANF administration inhibits stimulated vasopressin increase [62].

This brief outline of the characteristics of ANF helps explain why the discovery of this novel volumeregulating hormone, linking the heart - now known to be an endocrine organ - with kidney, adrenal cortex, microvasculature and the brain, has created so much excitement. Cardiologists, nephrologists and hepatologists are awaiting information on the possible impact of ANF in various diseases. This review will concentrate on the role of ANF in cirrhosis; in this pathologic state, the splanchnic and peripheral subcompartment are volume-overloaded, in contrast to the central volume-stimulation of congestive heart failure.

\section{Plasma levels}

As mentioned above, in cirrhotic patients with splanchnic sequestration of extracellular volume, supporters of the 'underfilling' theory might expect a diminution of centrally effective blood volume, resulting in decreased stimulation of ANF release and thus in lower ANF plasma levels. In contrast, if one believes in the 'overflow' theory of increased effective blood volume, elevated ANF levels might be anticipated. The first report concentrating on ANF plasma levels in cirrhosis [63] demonstrated in 9 cirrhotics without and 10 with ascites that there was no absolute deficiency of plasma ANF as compared to controls. Concentrations in patients with ascites did not differ from those in the other cirrhotics. In the course of the year that has elapsed since the appearance of that report and the submission of this review, several groups have investigated ANF levels in cirrhosis (Refs. 64-77; cf. Table 1). Levels lower than in controls were reported by one group only [65], in cirrhotics with ascites. In all of the studies that evaluated the presence or absence of ascites, the ANF concentrations observed were not markedly different from normal in the cirrhotics without ascites $[65,66$, $70,76]$. In patients with ascites, ANF values equal to $[66,68,70,75,77]$, lower [65] or higher $[67,69,72-74$. 76] than normal have been found. Differences in a number of factors might cause such different results: plasma extraction, radioimmunoassay, posture of the subjects, restriction of dietary sodium and water, diuretic treatment, or possibly variations in hepatic and renal clearance of ANF [78]. The atrial content of ANF, estimated by bioassay, was found to be higher than normal in human cirrhotic subjects [79], but lower than normal in cirrhotic rats [80].

Patients with congestive heart failure, characterized by central volume overload, exhibit markedly elevated ANF levels ranging from several up to one hundred times higher than normal $[43,81,82]$. Interestingly, further characterization of the immunoreactive ANF by HPLC techniques revealed an immunoreactive component of higher molecular weight in some of these patients (Fig. 3). It was speculated that the rate of compensatory ANF secretion upon the volume stimulus exceeded the capacity of the processing enzymes, thus resulting in the release of immature ANF of possibly reduced biological activity [83]. However, the above-mentioned reports on markedly elevated ANF plasma levels in cirrhotic patients do not provide a further characterization of the immunoreactivity. High performance gel permeation chromatography of ANF in cirrhosis has been performed in a few patients (Ref. 83, Fig. 3) and revealed only trace amounts of higher molecular weight forms. 


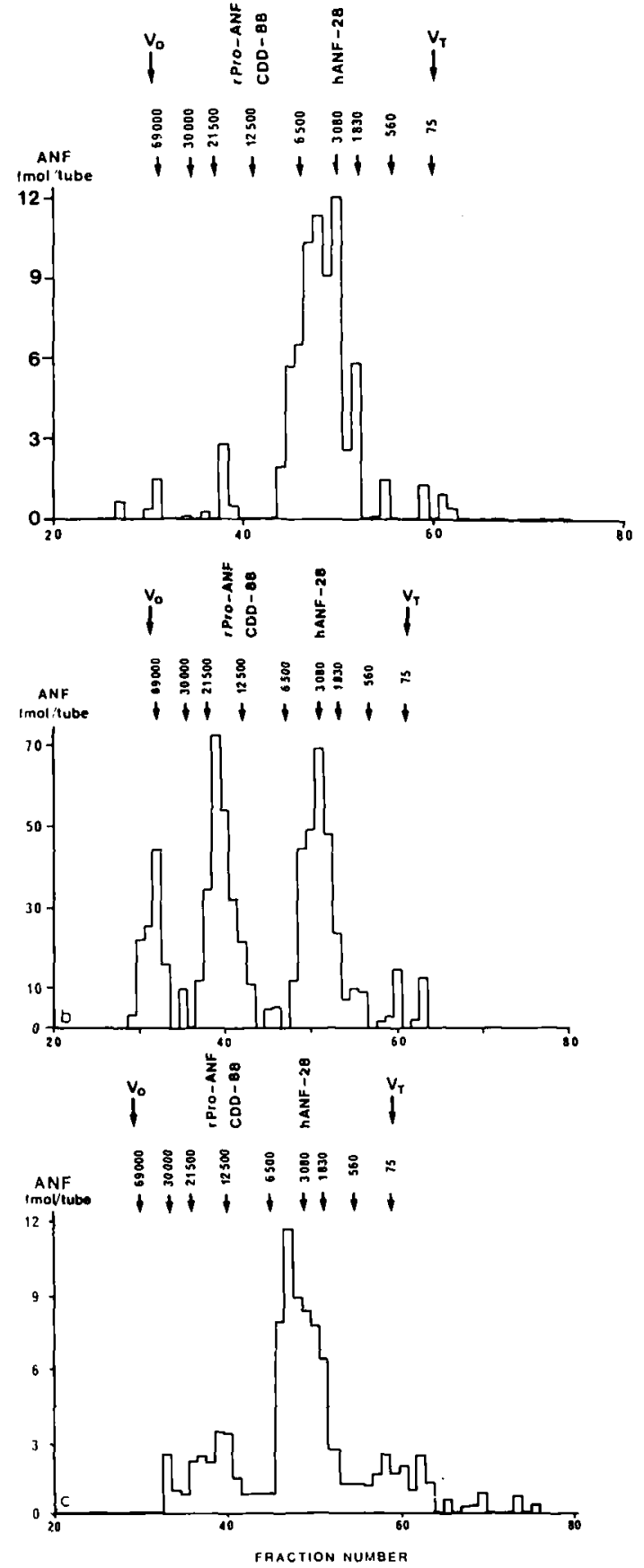

Fig. 3. Molecular weight pattern of immunoreactive ANF in a representative healthy subject $(a)$, a patient with severe congestive heart failure $(b)$ and a patient with cirrhosis $(c)$. In healthy subjects, plasma ANF consists virtually exclusively of ANF-28. In patients with CHF, higher molecular weight forms can be found that are to be seen only in trace amounts in the cirrhotic patient. Molecular weight calibration of the TSK 125 Bio-Sil column is indicated at the top of the illustration.

\section{ANF release}

Apart from inappropriate plasma levels or alterations of posttranslational processing, release of ANF to volume stimulation might be impaired. Head-out water immersion has been shown to be a useful model for investigating the response of the ANF system to acute volume stimulation in healthy subjects [38]. One-hour immersion in a thermoneutral bath induces a two-fold rise in ANF plasma levels (Fig. 4). Numerous investigations had shown that water immersion can also be conveniently used in cirrhotic patients [84] to study volume regulation. ANF release after 1-h immersion has been found to be normal in cirrhotics without ascites, but reduced to about one-half in the presence of ascites [85] (Fig. 5). These findings are at variance with another study demonstrating ANF increases twice as high as in normals in patients with ascites and edema [68]. Another group reported blunted ANF stimulation following water immersion in cirrhotics with ascites [69]. In view of a lack of increase in their control group, however, this assertion has been questioned [86].

\section{Renal response}

The natriuretic response to elevated ANF following water immersion has been found to be variable

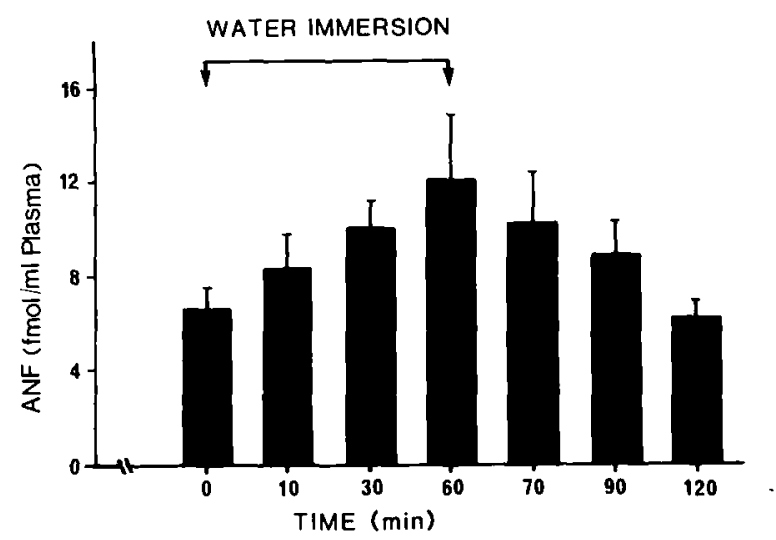

Fig. 4. ANF plasma levels before, during $60 \mathrm{~min}$ water immersion, and subsequent to immersion. Mean values and standard deviations of 12 healthy subjects. 


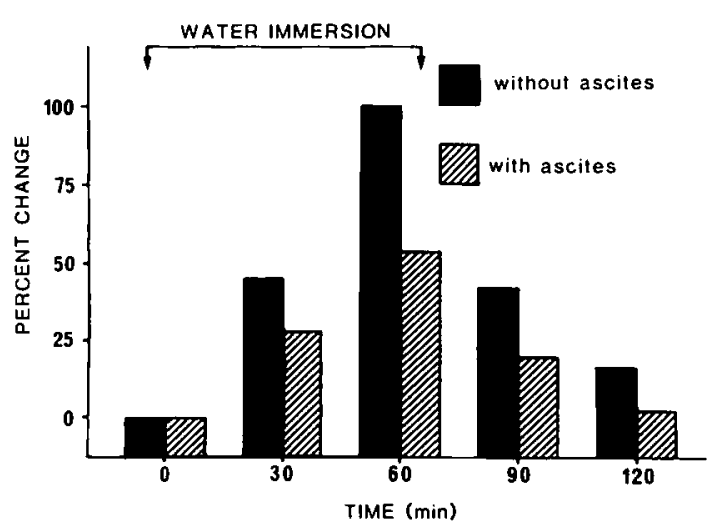

Fig. 5. Percent increase of plasma ANF during water immersion. Mean values of 7 patients with and 7 patients without ascites. Whereas cirrhotics without ascites exhibit normal increase, stimulation is blunted in patients with ascites.

$[68,70]$. Thus, stimulus-response coupling may be impaired in cirrhosis [87]. However, in patients with refractory ascites, insertion of a peritoneo-venous shunt increased ANF plasma levels, with a corresponding rise in natriuresis and diuresis [66,67]. Infusion of synthetic human ANF-28 in healthy subjects results in marked diuresis and natriuresis [88-90]. Similar beneficial effects have been observed in patients with cardiovascular disease, despite increased basal values $[82,91]$. The initial experience in a patient with refractory ascites, with infusion of 50 $\mathrm{ng} / \mathrm{kg} / \mathrm{min}$ for $60 \mathrm{~min}$ and resultant diuresis (Fig. 6) [92], encouraged other studies with therapeutic aspects. Eight of 14 cirrhotics responded to an i.v. bolus injection of $1 \mu \mathrm{g} / \mathrm{kg}$ with a significant increase of sodium excretion and urine flow, similar to the response of healthy controls [93]. Six patients, however, showed no marked effects. Plasma aldosterone was decreased in all cirrhotics, an effect that has not, as yet, been observed in all healthy subjects studied $[89,90]$. Renal response to ANF seems to be highly variable $[94,95]$, and limited effects of continuous infusion have been reported [94]. At this early stage of investigation of ANF in liver disease, it seems impossible to make unequivocal conclusions as to any dysfunction of stimulus-response-coupling.

\section{Therapeutic aspects}

Conventional diuretic therapy of ascites has been shown to involve hazards [96]. Thus, application of a naturally occurring diuretic hormone might seem promising. The diuretic, natriuretic and anti-hypertensive effects of ANF could be of therapeutic relevance in clinical practice, especially when long-acting analogues will be developed. In patients with endstage heart failure on intensive care, i.v. ANF administration might prove helpful in improving cardiopulmonary hemodynamics (Arendt, R.M. and Gerbes. A.L., unpublished observation). Upon administering the peptide to cirrhotics, in whom the Renin-Angiotensin-Aldosterone system is often activated to

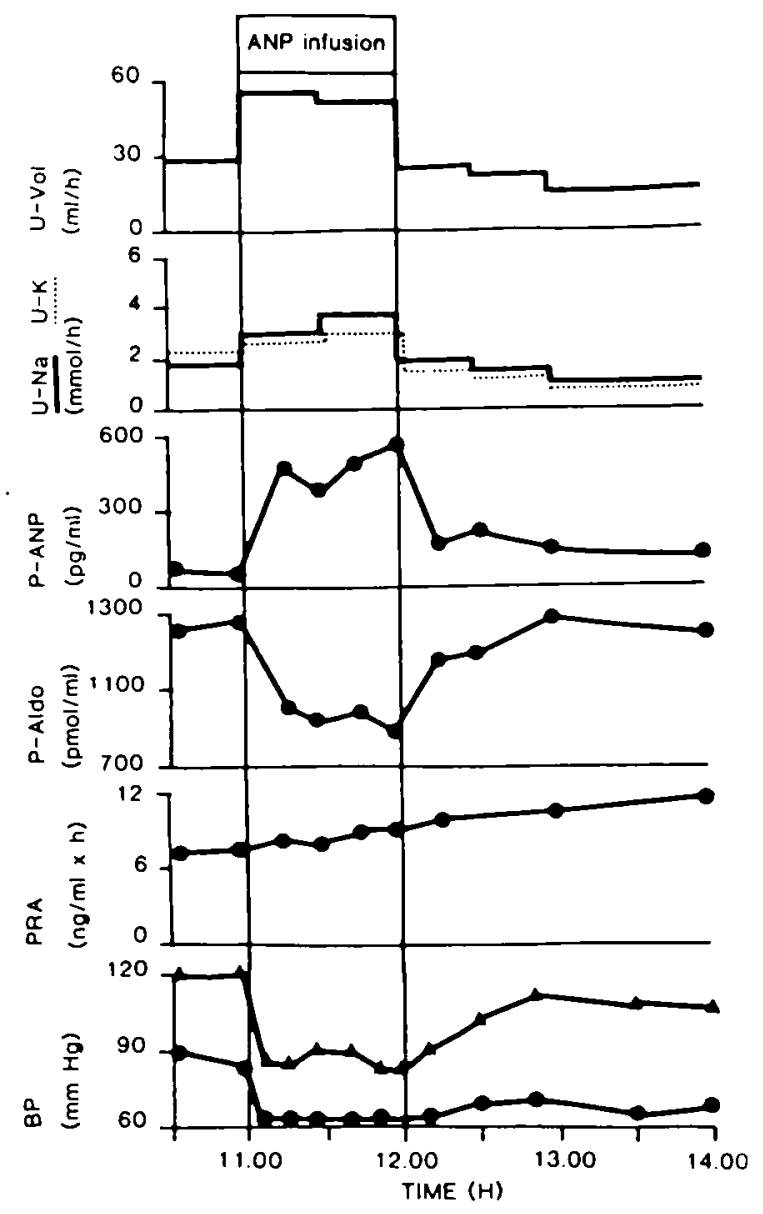

Fig. 6. Effects of ANF infusion in a patient with cirrhosis and ascites (from Ref. 92). 
maintain their blood pressure, special attention should be given to the antihypertensive effects. Slight to marked decreases of mean arterial pressure following ANF injection have been observed [93]: 2-10 minutes after injection, mean arterial pressure decreased more markedly in cirrhotics $(18 \pm 5 \mathrm{~mm} \mathrm{Hg})$ than in controls $(8 \pm 4 \mathrm{~mm} \mathrm{Hg}$ ) [93]. However, with its modes of action differing from that of established diuretics [97], the therapeutic potentials of ANF should be studied in greater detail.

\section{Summary}

The discovery of the first well-defined natriuretic hormone, the Atrial Natriuretic Factor (ANF), has prompted research on its impact on volume regulation in health and disease. The natriuretic, diuretic,

\section{References}

1 Sherlock S. Ascites formation in cirrhosis and its management. Scand J Gastroenterol 1970; suppl 7: 9-15.

2 Epstein FH. Underfilling versus overflow in the hepatic ascites. N Engl J Med 1982; 307: 1577-1578.

3 Wilkinson S, Williams R. Renin-angiotensin-aldosterone system in cirrhosis. Gut 1980; 21: 545-554.

+ Wernze H, Spech HI, Müller G. Studies on the activity of the renin-angiotensin-aldosterone system (RAAS) in patients with cirrhosis of the liver. Klin Wochenschr 1978; 36: 389-397.

5 Rosoff L, Zia P, Reynolds T, Horton R. Studies of renin and aldosterone in cirrhotic patients with ascites. Gastroenterology 1975; 69: 698-705.

6 Ring-Larsen H, Henriksen JH, Christensen NJ. Increased sympathetic activity in cirrhosis. N Engl J Med 1983; 308: 1029-1030.

7 Bichet DG, Van Putten VJ, Schrier RW. Potential role of increased sympathetic activity in impaired sodium and water excretion in cirrhotic patients. N Engl J Med 1982; 307: $1552-1557$

8 Bichet D, Szatalowicz V, Chaimowitz C, Schrier RW. Role of vasopressin in abnormal water excretion in cirrhotic patients. Ann Intern Med 1982; 96: 413-417.

9 Zipser RD, Hoefs JC, Speckart PF, Zia PK, Horton R. Prostaglandins. Modulators of renal function and pressor resistance in chronic liver disease. J Clin Endocrinol Metab 1979; 48: 895-900.

10 Laffi G, La Villa G, Pinzani M, et al. Altered renal and platelet arachidonic acid metabolism in cirrhosis. Gastroenterology 1986; 90: 274-282. and smooth muscle-relaxing properties suggest an important role of this novel hormone in pathophysiological states with sodium or volume retention, such as congestive heart failure or cirrhosis of the liver. Investigations on the implications of ANF in liver disease have been performed for little more than 1 year, and results are still controversial in many respects. At present, it seems very likely that there is no absolute deficiency of plasma ANF in patients with cirrhosis. Moreover, elevated plasma levels in cirrhotics with ascites have been reported by several groups. However, as yet, a molecular characterization of this increased immunoreactivity is still lacking. There is disagreement on the reduced release of and renal response to ANF in subgroups of cirrhotics; however, stimulus-response-coupling might be impaired. Further studies are needed to elucidate the pathophysiological implications and therapeutical potential of ANF in patients with chronic liver disease.

11 Wong PY. The kallikrein-kinin and related vasoactive systems in cirrhosis of the liver. In: Epstein M, ed. The Kidney in Liver Disease. 1st ed. New York: Elsevier/North-Holland Biomedical Press, 1978; 299-310.

12 Bourgoignie O, Hwang KH, Espinel C, Klahr S, Bricker NS. A natriuretic factor in the serum of patients with chronic uraemia. J Clin Invest 1972; 51: 1514-1527.

13 Bricker NS, Klahr S, Purkerson M, Schultze RG, Avioli LA, Birge SJ. In vitro assay for a humoral substance present during volume expansion and uraemia. Nature 1968; 219: 1058-1059.

14 Buckalew VM, Gruber KA. Natriuretic hormone. In: Epstein M, ed. The Kidney in Liver Disease. 1st ed. New York: Elsevier/North-Holland Biomedical Press, 1983; 479-499.

15 DeWardener HE, Clarkson EM. Concept of natriuretic hormone. Physiol Rev 1985; 65: 658-759.

$16 \mathrm{Kramer}$ HJ. Natriuretic hormone - its possible role in fluid and electrolyte disturbances in chronic liver disease. Postgrad Med J 1975; 51: 532-540.

17 Epstein M. Natriuretic hormone and the sodium retention of cirrhosis. Gastroenterology 1981; 81: 395-399.

18 Hartshorne $\mathrm{H}$. Water versus hydrotherapy or an essay on water and its true relations to medicine. Philadelphia: Lloyd P. Smith, 1847; 28.

19 Gauer $\mathrm{OH}$, Henry JP. Circulatory basis of fluid volume control. Physiol Rev 1963; 43: 423-481.

20 Henry JP, Gauer O, Reeves IL. Evidence of the atrial location of receptors influencing urine flow. Circ Res 1956; 4: 85-90.

21 Bompiani GD, Rouiller $\mathrm{CH}$, Hatt PY. Le tissue de conduction du coeur chez le rat. Etude au microscope électron- 
ique. Arch Mal Coeur 1959; 52: 1257-1267.

22 Kisch B. Electron microscopy of the atrium of the heart. Exp Med Surg 1956; 14: 99-112.

23 DeBold AJ, Borenstein HB, Veress AT. Sonnenberg H. A rapid and potent natriuretic response to intravenous injection of atrial myocardial extracts in rats. Life Sci 1981; 28: 89-94.

24 Anderson JV, Bloom SR. Atrial natriuretic peptide: what is the excitement all atout? J Endocrinol 1986; 110: 7-17.

25 Arendt RM, Gerbes AL. Atrialer natriuretischer Faktor. Die endokrine Funktion des Herzens. Dtsch Med Wochenschr 1986; 111: 1849-1857.

26 Atlas SA, Laragh JH. Atrial natriuretic peptide: a new factor in hormonal control of blood pressure and electrolyte homeostasis. Annu Rev Med 1986; 37: 397-414.

27 Ballermann BJ, Brenner BM. Biologically active atrial peptides. J Clin Invest 1985; 76: 2041-2048.

28 DeBold AJ. Atrial natriuretic factor: an overview. Fed Proc 1986; 45: 2081-2085.

29 Forssmann WG. Cardiac hormones. Review on the morphology, biochemistry and molecular biology of the endocrine heart. Eur J Clin Invest 1986; 16: 439-451.

30 Gerzer R. Das Herz, ein endokrines Organ. Klin Wochenschr 1985; 63: 529-536.

31 Maack T, Kleinert HD. Renal and cardiovascular effects of atrial natriuretic factor. Biochem Pharmacol 1986; 35: 2057-2064.

32 Needleman P. Atriopeptin: biochemical pharmacology. Fed Proc 1986; 45: 2096-2100.

33 Sagnella GA, MacGregor GA. Cardiac peptides and the control of sodium excretion. Nature 1984; 309: 666-667.

34 Thibault G, Garcia R, Gutkowska J, Genest J, Cantin M. Atrial natriuretic factor. A newly discovered hormone with significant clinical implications. Drugs 1986; 31: 369-375.

35 Arendt RM, Stangl E, Zähringer J, Liebisch DC, Herz A. Demonstration and characterization of $\alpha$-human atrial natriuretic factor in human plasma. FEBS Lett 1985; 189: $57-62$.

36 Needleman PJ, Greenwald JE. Atriopeptin: a cardiac hormone intimately involved in fluid, electrolyte, and bloodpressure homeostasis. N Engl J Med 1986; 314: 828-834.

37 Sagnella GA, Markandu ND, Shore AC, MacGregor GA. Effects of changes in dietary sodium intake and saline infusion on immunoreactive atrial natriuretic peptide in human plasma. Lancet 1985; ii: 1208-1211.

38 Gerbes AL, Arendt RM, Schnizer W, et al. Regulation of atrial natriuretic factor release in man: effect of water immersion. Klin Wochenschr 1986; 64: 666-667.

39 Anderson J, Struthers A, Christofides N, Bloom S. Atrial natriuretic peptide: an endogenous factor enhancing sodium excretion in man. Clin Sci 1986; 70: 327-331.

40 Epstein M, Loutzenhiser R, Friedland E, Aceto RM, Camargo MIF, Atlas SA. Relationship of increased plasma atrial natriuretic factor and renal sodium handling during immersion-induced central hypervolemia in normal humans. J Clin Invest 1987; 79: in press.

40a Ogihara T, Shima J, Hara H, et al. Significant increase in plasma immunoreactive atrial natriuretic peptide concentration during head-out water immersion. Life Sci 1986; 38 : 2413-2418.
41 Lang RE, Thölken H, Ganten D, Luft FC, Ruskoaho H. Unger T. Atrial natriuretic factor: a circulating hormonc stimulated by volume loading. Nature $1985 ; 314: 264-265$.

42 National Institute for Biological Standards and Control. Holly Hill, Hampstead, London, NW3 6RB, United King. dom (Feb 1986). Invitation Letter.

43 Arendt RM, Gerbes AL, Ritter D, Stangl E, Bach P, Zäh ringer $\mathrm{J}$. Atrial natriuretic factor in plasma of patients with arterial hypertension, heart failure or cirrhosis of the liver. J Hypertension 1986; 4(suppl 2): S131-S135.

44 Gerzer R, Weil J, Strom T, Müller T. Mechanisms of action of atrial natriuretic factor. Clinical consequences. Klin Wochenschr 1986; 64(suppl VI): 21-26.

45 Marin-Grez M, Fleming JT, Steinhausen M. Atrial natriuretic peptide causes pre-glomerular vasodilation and postglomerular vasoconstriction in rat kidney. Nature 1986 : 324: 473-476.

46 Biollaz J, Waeber B, Nussberger J, et al. Atrial natriuretic peptides: reproducibility of renal effects and responses of liver blood flow. Eur J Clin Pharmacol 1986; 31: 1-8.

47 Naruse M, Obana K, Naruse K, et al. Antisera to atrial nittriuretic factor reduces urinary sodium excretion and increases plasma renin activity in rats. Biochem Biophys Res Commun 1985; 132: 954-960.

48 Cuneo RC, Espiner EA, Nicholls MG, Yandle TG, Joyce SL, Gilchrist NI. Renal, hemodynamic, and hormonal rcsponses to atrial natriuretic peptide infusions in normal man, and effect of sodium intake. J Clin Endocrinol Metab 1986; 63: 946-953.

49 Laragh JH. Atrial natriuretic hormone, the renin-aldosterone axis, and blood pressure-electrolyte homeostasis. $\mathrm{N}$ Engl J Med 1985; 313: 1339-1340.

50 Goodfriend TL, Elliott ME, Atlas SA. Actions of synthetic atrial natriuretic factor on bovine adrenal zona glomerulosa. Life Sci 1984; 35: 1675-1682.

51 Chartier L, Schiffrin E, Thibault G, Garcia R. Atrial naltriuretic factor inhibits the stimulation of aldosterone secretion by angiotensin II, ACTH and potassium in vitro and angiotensin II-induced steroidogenesis in vivo. Endocrinology 1984; 115: 2026-2028.

52 Yamaji J, Ishibashi M, Sekihara H, Takaku F, Nakaoka H, Fujii J. Plasma levels of atrial natriuretic peptide in primary aldosteronism and essential hypertension. J Clin Endocrinol Metab 1986; 63: 815-818.

53 Ames RP, Borkowski AJ, Sicinski AM, Laragh JH. Prolonged infusions of angiotensin II and norepinephrine and blood pressure, electrolyte balance, and aldosterone and cortisol secretion in normal man and in cirrhosis with ascites. J Clin Invest 1965; 44: 1171-1186.

54 Ballermann BJ, Bloch KD, Seidman JG, Brenner BM. Atrial natriuretic peptide transcription, secretion, and glomeralar receptor activity during mineralocorticoid escape in the rat. J Clin Invest 1986; 78: 840-843.

55 Wambach G, Götz S, Suckau G, Kaufmann W. Plasma levels of atrial natriuretic peptide (ANP) during mineralocorticoid escape in normal man. Klin Wochenschr 1986; 64(suppl VI): 53-57.

56 De Wardener HE, Mills IH, Clapham WF, Hayter CJ. Studies on the efferent mechanism of the sodium diuresis which follows the administration of intravenous saline in 
the dog. Clin Sci 1961; 21: 249-258.

57 Currie MG, Newman WH. Evidence for $\alpha-1$ adrenergic receptor regulation of atriopeptin release from the isolated rat heart. Biochem Biophys Res Commun 1986; 137: 94-100.

58 Schafferhans K, Heidbreder E, Grimm D, Heidland A. Human atrial natriuretic factor prevents against norepinephrine-induced acute renal failure in the rat. Klin Wochenschr 1986; 64(suppl VI): 73-77.

59 Uehlinger DE, Weidmann P, Gnädiger MP, Shaw S, Lang RE. Depressor effects and release of atrial natriuretic peptide during norepinephrine or angiotensin II infusion in man. J Clin Endocrinol Metab 1986; 63; 669-674.

60 Ganger DR, Traber PG, Gutkowska J, Gottstein J, Blei AT. The renal effects of vasopressin and nitroglycerin, and its relation to atrial natriuretic peptide [Abstract]. Hepatology $1986 ; 6: 1185$.

61 Manning PT, Schwartz D, Katsube NC, Holmberg SW, Needleman P. Vasopressin-stimulated release of atriopeptin: endocrine antagonists in fluid homeostasis. Science 1985; 229: 395-397.

62 Samson WK. Atrial natriuretic factor inhibits dehydration and hemorrhage-induced vasopressin release. Neuroendocrinology 1985; 40: 277-279.

63 Gerbes AL, Arendt RM, Ritter D, Jüngst D, Zähringer J, Paumgartner $G$. Plasma atrial natriuretic factor in patients with cirrhosis. N Engl J Med 1985; 313: 1609-1610.

64 Barakat SN, Walsh MF, Zuireck S, Sowers JR. Immunoreactive atrial natriuretic peptide (ANP) levels in a volume expanded black patient population. First World Congress on Biologically Active Atrial Peptides, New York, 1986, abstract $80 \mathrm{~A}$.

65 Bonkovsky H, Hartle D, Simon D, Mellen B, Kutner M, Galambos J. Decreased plasma atrial natriuretic peptides in cirrhotic ascitic patients [Abstract]. Hepatology 1986; 6: 1213.

66 Burghardt W, Wernze H, Diehl KL. Atrial natriuretic peptide in hepatic cirrhosis: relation to stage of disease, sympathoadrenal system and renin-aldosterone axis. Klin Wochenschr 1986; 64(suppl VI): 103-107.

67 Campbe!l P, Blendis LM, Skorecki K, Logan A, Wong PY, Greig P. The effect of peritoneovenous shunting (PVS) on plasma immunoreactive atrial natriuretic peptide (ANP) levels in hepatic ascites [Abstract]. Hepatology 1986; 6: 1120.

68 Epstein M, Preston R, Aceto R, Camargo MJF, Loutzenhiser $R$, Atlas $S$. Dissociaton of plasma irANF and renal sodium handling in cirrhotic humans undergoing water immersion [Abstract]. Kidney Int 1987; in press.

49 Fernandez-Cruz A, Marco J, et al. Plasma levels of atrial natriuretic peptide in cirrhotic patients. Lancet 1985; ii: 1439-1440.

70 Gerbes AL, Wernze H, Arendt R, et al. Effect of water immersion (WI) on renal sodium handling in cirrhosis: relation to atrial natriuretic factor (ANF) and sympathetic nervous activity [Abstract]. Hepatology 1986; 6: 1159.

71 Ginés P, Jimenez W, Navasa M, et al. Atrial natriuretic factor (ANF) in cirrhosis. Plasma levels, cardiac release and splanchnic extraction [Abstract]. J Hepatol 1986; 3(suppl 1): $\$ 30$.
72 Jüppner H, Brabant G, Kapteina U, Kirschner M, Klein H, Hesch RD. Direct radioimmunoassay for human atrial natriuretic peptide (hANP) and its clinical evaluation. Biochem Biophys Res Commun 1986; 139: 1215-1223.

73 Morgan T, Imada T, Inagami T. Atrial natriuretic protein (ANP) in the hepatorenal syndrome [Abstract]. Hepatology 1986; $6: 1215$.

74 Nishiuchi T, Saito H, Yamasaki Y, Saito S. Radioimmunoassay for atrial natriuretic peptide: method and results in normal subjects and patients with various diseases. Clin Chim Acta 1986; 159: 45-57.

75 Nozuki M, Mouri T, Itoi K, et al. Plasma concentrations of atrial natriuretic peptide in various diseases. Tohoku J Exp Med 1986; 148: 439-447.

76 Renner F, Hartter E, Pidlich J. Atrial natriuretic peptide, hepatic cirrhosis and ascites. VII. International Basel Liver Week, Basel, 1986, abstract.

77 Shenker Y, Sider RS, Ostafin EA, Grekin RJ. Plasma levels of immunoreactive atrial natriuretic factor in healthy subjects and in patients with edema. J Clin Invest 1985; 76: 1684-1687.

78 Richards AM, Cleland IGF, Tonolo G, et al. Plasma natriuretic peptide in cardiac impairment. $\mathrm{Br}$ Med J 1986; 293: 409-412.

79 Valdivieso A, Rosas R, Villalon P, Croxatto H. Effects of cirrhotic human atrial extracts on blood pressure, diuresis, urinary electrolytes and kallikrein excretion in the rat. Meeting of the International Society for Hypertension, Heidelberg, 1986, abstract 1369.

80 Jimenez W, Martinez-Pardo A, Arroyo V, Gaya I, Rivera F. Rodés J. Atrial natriuretic factor: reduced cardiac content in cirrhotic rats with ascites. Am J Physiol 1986; 250: F749-F752.

81 Burnett JC, Kao PC. Atrial natriuretic peptide elevation in congestive heart failure in the human. Science 1986; 231 : $1145-1147$

82 Richards AM, Nicholls MG, Espiner EA. Effects of $\alpha$-human atrial natriuretic peptide in essential hypertension. Hypertension 1985; 7: 812-817.

83 Arendt RM, Gerbes AL, Ritter D, Stangl E. Molecular weight heterogeneity of plasma-ANF in cardiovascular disease. Klin Wochenschr 1986; 64(suppl VI): 97-102.

84 Epstein M. Pathogenesis of renal sodium handling in cirrhosis. Am J Nephrol 1983; 3: 297-309.

85 Gerbes AL, Arendt RM, Riedel A, et al. Role of the atrial natriuretic factor (ANF) in volume regulation of healthy and cirrhotic subjects. Effects of water immersion [Abstract]. Gastroenterology 1986; 90: 1727.

86 Gerbes AL, Arendt RM, Zähringer J, Paumgartner G. Atrial natriuretic peptide, the sympathetic nervous system, and decompensated cirrhosis. Lancet 1986; i: 331.

87 Gerbes AL, Arendt RM, Jüngst D, Sauerbruch T, Paumgartner G. Impaired stimulation of ANF in patients with cirrhosis and ascites. Second World Congress on Biologically Active Atrial Peptides, New York, 1987, abstract 54.

88 Tikkanen I, Fyhrquist F, Metsärinne K, Leidenius R. Plas: ma atrial natriuretic peptide in cardiac disease and during infusion in healthy volunteers. Lancet 1985; ii: 66-69.

89 Richards AM, Nicholls MG, Ikram H, Webster MWI, Yandle TG, Espiner EA. Renal, haemodynamic, and hormonal 
effects of human alpha atrial natriuretic peptide in healthy volunteers. Lancet 1985; i: 545-548.

90 Weidmann P, Hasler L, Gnädiger MP, et al. Blood levels and renal effects of atrial natriuretic peptide in normal man. J Clin Invest 1986; 77: 734-742.

91 Riegger AJ, Kromer EP, Kochsiek K. Der natriuretische Vorhoffaktor bei schwerer kongestiver Herzinsuffizienz. Dtsch Med Wochenschr 1985; 110: 1607-1611.

92 Fyhrquist F, Tötterman KJ, Tikkanen I. Infusion of atrial natriuretic peptide in liver cirrhosis with ascites. Lancet 1985; ii: 1439.

93 Salerno F, Badalamenti S, Incerti PL, Mainardi L, Capozza L. Reduced natriuretic response to atrial natriuretic pep- tide (ANP) in patients with advanced liver cirrhosis [Abstract]. J Hepatol 1986; 3(suppl 1): \$80.

94 Brabant G, Jüppner H, Kirschner M, Böker K, Schmidt FW, Hesch RD. Human atrial natriuretic peptide (ANP) for the treatment of patients with liver cirrhosis and ascites. Klin Wochenschr 1986; 64(suppl VI): 108-111.

95 Gerbes AL. Neuere Aspekte in Diagnose und Therapie des Aszites. Z Gastroenterol 1987; in press.

96 Conn HO. Diuresis of ascites: fraught with or free from hazard. Gastroenterology 1977; 73: 619-621.

97 Shimizu T, Nakamura M. Renal effect of atrial natriuretic polypeptide: comparison with standard saluretics. Eur J Pharmacol 1986; 127: 249-259. 